\title{
Who is More Accountable? Federal or State Malaysian Statutory Bodies
}

\author{
Nurhidayah Yahya*, Jamaliah Said and Nor Balkish Zakaria \\ Accounting Research Institute, Universiti Teknologi MARA, Malaysia
}

\begin{abstract}
The World Bank on Governance Indicators in the aspect of 'Voice and Accountability' reported accountability for Malaysia had declined to $34 \%$ in 2017 from 37\% in 2013. Data from the International Country Risk Guide showed a decrease in accountability since 2011 from 4.46 to 4 points out of 6 points in the year 2012. Public sector organisations like statutory bodies might also face issues of accountability. This study aims to evaluate and compare the accountability outcomes of federal and state statutory bodies through a questionnaire. The measurement for accountability based on four dimensions, namely transparency, evaluation, stakeholders' participation and complaint and response. Based on 194 responses received from top management of Malaysian statutory bodies, the overall accountability outcome has shown an above average score of 5.97 for both federal and state statutory bodies. This shows that Malaysian statutory bodies have delivered a high level of accountability. The test for the difference between the means scores of independent T-tests also shows that there is no significant difference between the accountability level of federal and state statutory bodies. Despite the different level of obligation and legislation, both types of statutory bodies seem to deliver an equally high level of accountability outcomes.
\end{abstract}

Keywords: Accountability, transparency, stakeholders' participation, evaluation, complaint and response, federal statutory bodies, state statutory bodies.

JEL Classification: H83

Paper Type: Research 


\section{INTRODUCTION}

Public sector organisations must serve the best for the public. Thus, accountability was vital in servicing and gain public confidence in managing the public fund. The era of New Public Management (NPM) and current New Public Governance (NPG) focused on accountability and emphasis on service delivery to the public (Hyndman \& Liguori, 2016; Osborne, 2006, 2010; Osborne, Radnor, \& Nasi, 2012). Accountability was viewed as a performance indicator for the public sector (Behn, 2001; Dubnick \& Frederickson, 2011) and responsibilities to the stakeholders (Bovens, 2007; Lindkvist \& Llewellyn, 2003). The accomplishment of high accountability was a reflection of organisation effectiveness in meeting multiple goals (Engelen, Gupta, Strenger, \& Brettel, 2015). Hence, accountability was crucial as the achievement of high performance of government's organisations.

Government of Malaysia had come out with several mechanisms like the Auditor General Report and evaluation through Star Rating Index by The Malaysian Administrative Modernisation and Management Planning Unit (MAMPU) for accountability requirements. However, it had been highlighted that Malaysia public sectors had issues with lack of accountability (Siddiquee, 2005). Data from the International Country Risk Guide showed a decrease in accountability since 2011 from 4.46 to 4 points out of 6 points in the year $2012^{1}$. The points remained at 4 until the year 2016. These showed that Malaysia did have issues with accountability.

Through the report by The World Bank on Governance Indicators in the aspect of 'Voice and Accountability' showed Malaysia's score had declined which only scored $34 \%$ in the year 2017, 2016 and 2015 from 37\% in 2013 and 35\% in 2014 ${ }^{2}$. Further, Auditor's General report also highlighted the weaknesses of Malaysia government organisations, including statutory bodies.

This study focuses on both federal and state statutory bodies, aims to determine and compare the level of accountability of statutory bodies in Malaysia accordingly. The measurement of accountability used encompassed the dimensions of transparency, stakeholders' participation, evaluation and complaint and response - the study endeavour to use these elements and primary data as a method of data collection.

\section{FEDERAL STATUTORY BODIES VS STATE STATUTORY BODIES}

Statutory bodies were public organisations with the same basis as other government activities and subject to executive and legislative control (Seidman, 1954). Statutory bodies emphasised on the process which promotes the societal value and had a high level of citizen involvement and responsiveness to the needs and interest of the society (Denhardt, 2008). They were financed by government grants, and they were also expected to generate their income. The statutory bodies' business activities comprised many integration and autonomy arena, which involved demand from government, state, market and society (Thynne, 2006) which play a crucial part of country development and progress. In terms of financial management, the statutory bodies had their financial regulations, systems and procedures and accounting policies.

Statutory bodies were established to deliver government policies through their operations of services, programmes and activities. It was challenging for statutory bodies' operations since they were complex and covered diverse scopes. Statutory bodies were also complex because they involved with government-related initiatives, developments in

\footnotetext{
${ }^{1}$ Retrieved from https://epub.prsgroup.com/

${ }^{2}$ Retrieved from http://info.worldbank.org/governance/wgi/index.aspx\#reports and http://info.worldbank.org/governance/wgi/\#reports
} 
information technology and communication, and higher demands for assurance and results (Barrett, 2002a). They were subjected to their incorporation Act or subsidiary incorporation legislation which set out the purpose and specific powers of autonomy, and they functioned according to their objectives. Nevertheless, the Board of Directors were established and authorised for management, administration, and activities of statutory bodies.

In Malaysia, there were two tiers of statutory bodies which were federal and state statutory bodies. The federal statutory bodies were set up by parliament and incorporated following the Federal law to execute government policies through their programmes and activities (National Audit Department Malaysia, 2015b). Each federal statutory body was placed under a ministry in charge as required by the incorporation legislation. They had subsidiaries and branches to ensure the efficiency of services delivered to the public. Therefore, any good or bad news happened, whether, at the headquarters or subsidiaries or branches level, the whole organisation would be affected. They were formed to be the arm and legs of every ministry to perform and carry out the task in providing services to the public. An example of federal statutory bodies was Central Bank of Malaysia, which was a statutory body under the Ministry of Finance (National Audit Department Malaysia, 2015a).

Further, in federal statutory bodies, the Board of Directors consisted of members such as a representative from the Ministry of Finance, representative from the related ministries, Chief Executive Officer and his deputies, secretary, government officers and corporate members who had relevant expertise in the statutory body's activities. The selection and termination of board members were under the jurisdiction of the Minister. Federal statutory bodies submitted their audited financial statement to their respective ministers. The ministers later tabled them in the Parliament (National Audit Department Malaysia, 2015b).

On the other hand, for the states statutory bodies, they were incorporated base on each state government's enactments and laws. Their main activities were for the maintenances and development of the states. Examples of state statutory bodies were Selangor State Development Corporation for the state of Selangor, Sabah Rubber Industry Board for the state of Sabah and Kelantan Public Library Corporation for the state of Kelantan. As for the states statutory bodies, the Board was chaired by the state's Chief Minister and the deputy would be the state government's secretary. The Board members consisted of directors from related departments of the statutory bodies' business activities, and some had representatives from relevant federal ministries. Their audited annual reports were tabled in State Legislative Assembly.

The issues of statutory bodies in Malaysia highlighted were also poor job quality, unreasonable delay in job completion, improper payment, and unreasonable project price (Shariman, Nawawi, \& Salin, 2018) which showed unaccountability. Information from Accountability Index Ranking System by Malaysian Auditor-General department for the year 2015 reported $4.2 \%$ of federal statutory bodies were rated as Excellent, $33.3 \%$ rated as Good, $50 \%$ were rated as Satisfactory and $12.5 \%$ were rated as Unsatisfactory with the performance of 4 agencies had deteriorated more than $90 \%$ as compared to their performance in 2012 (National Audit Department Malaysia, 2015b). For the year 2016 performance showed an improvement where $42.1 \%$ of federal statutory bodies are Excellent, 50\% rated as Good and 7.9\% rated as Satisfactory. Although 19 federal statutory bodies' performances increase for the year 2013 and 2016, 18 federal statutory bodies decrease in their performances (National Audit Department Malaysia, 2016g).

The same went for state statutory bodies. A further example can be seen in the Accountability Index Ranking System for the year 2015 showed that there was one Johor state statutory body rated as Less satisfactory and one Pulau Pinang state statutory body 
as Unsatisfactory ${ }^{3}$. As for the year 2016, Kedah's Accountability Index Ranking System rated one state statutory body as Less satisfactory (National Audit Department Malaysia, 2016a), Kelantan and Malacca have one state statutory bodies that rated as Less satisfactory and one as Unsatisfactory (National Audit Department Malaysia, 2016c, 2016b). One Pahang and Terengganu state statutory bodies score Less satisfactory (National Audit Department Malaysia, 2016f, 2016d) and Perlis one state statutory bodies Unsatisfactory (National Audit Department Malaysia, 2016e).

Therefore, both federal and state statutory bodies had accountability issues. Thus, this study determined the level of accountability for both statutory bodies in Malaysia according to the accountability's dimensions gathered through questionnaires. Further, the scores were compared to distinguish whether there were differences between both statutory bodies. This could be an indicator for future studies to collaborate with both federal and state statutory bodies if there were no significant difference between them both.

\section{LITERATURE REVIEW}

\subsection{Accountability}

Past scholars defined accountability as the relationship between people and organisations (Ebrahim, 2005). Some understood accountability as performance (Romzek, 2000). Others perceived it as an opinion on shared expectations of actions of the organisation to the community (Ammeter, Douglas, Ferris, \& Goka, 2004). According to One World Trust on Global Accountability Report, p. 11, accountability was the processes through which an organisation made a commitment to respond to and balanced the needs of stakeholders in its decision-making processes and activities, and delivers against this commitment (Lloyd, Oatham, \& Hammer, 2007).

Thus, accountability was social relationships which need justification and felt of obligation of an actor (OECD, 2013; Pollitt, 2003; Romzek \& Dubnick, 1987) which were the relationships between the state and society in providing better services. The actors were responsible for organisational performance and outcome (Behn, 2001; Bovens, 2010; Dubnick \& Frederickson, 2011). Accountability would be an impact on commitment and effectiveness (Simonson \& Staw, 1992), and the organisation's management's quality and productivity (Mohanty, 1993). Hence, accountability would suppose an organisation to be responsible and behave in certain manner to achieve its goals.

Accountability needed to be instilled. Greater accountability enhanced the performance of the government (Dubnick \& Frederickson, 2011). The issue of expectations was central to the entire accountability process. Institutionalizing accountability mechanism was one way to guarantee good government (Ackerman, 2004). Being accountable was to achieve expected performance, and the sign of accountability was performing accordingly to the standard (Dubnick \& Frederickson, 2011). Thus, all services should be improved, parallel with accountability to the stakeholders (Kloot, 1999). Therefore, accountability is vital to be achieved and elevated by public sector organisations, including statutory bodies.

Accountability and transparency were seen to have connections (Mabillard \& Zumofen, 2016). Accountability emphasised on openness which was transparency and focused on dialogue with stakeholder which was stakeholders' participation (Hanretty \& Koop, 2014; Hanretty, Larouche, \& Reindl, 2012; Lloyd et al., 2007; Lloyd, Warren, \& Hammer, 2008). Further, accountability's fundamental factors were information, debate

\footnotetext{
${ }^{3}$ Retrieved from https://www.audit.gov.my/index.php/2012-10-04-09-12-39/negeri
} 
and consequences (Reichersdorfer, Christensen, \& Vrangbaek, 2013) which were an evaluation of conducts and organisations' activities (Bovens, Goodin, \& Schillemans, 2014). Also, public organisations like statutory bodies needed to provide feedback and responses back to the internal and external stakeholders, especially for their complaint and response. It was vital for their satisfaction and trust. Therefore, the aspect of performance evaluation and complaint and response were also part of accountability (Hanretty et al., 2012; Lloyd et al., 2007, 2008). Overall, accountability encompassed the dimensions of transparency, the participation of stakeholders, evaluation and complaint and response (Hanretty et al., 2012; Lloyd et al., 2007, 2008).

\section{METHODOLOGY}

\subsection{Data Collection}

The questionnaires were distributed to 291 Malaysian statutory bodies, through an online survey from November 2017 until February 2018. There were 127 federal statutory bodies and 164 state statutory bodies. The respondents were Chief Executive Officer (CEO). CEOs were chosen as the respondent of the study as they knew the governance matters, updates and regulations requirements of the organisation.

\subsection{Measurement for Variables}

As the study adopts primary data method, the questions will be adapted from the World Accountability Report by One World Trust and previous related literature from Hanretty and Koop (2014), Hanretty et al. (2012), Kolk (2008) and Lloyd et al. (2007, 2008). The total items are 19 questions comprised of dimensions of transparency, evaluation, complaint and response, and stakeholders' participation. Seven Likert scales will be used to assess the level of agreement or disagreement of respondents for each question. The scale measured as $1=$ Strongly disagree, 2=Somewhat disagree, 3=Slightly disagree, 4=Neither disagree nor agree, 5=Slightly agree, 6=Somewhat agree, $7=$ Strongly agree.

\subsection{Data Analysis}

The data reliability of the current study was measured by utilizing the Cronbach's alpha test. Later, independent T-test was conducted, and the effect size was done accordingly to indicate whether there was a significant difference between the levels of accountability of federal and state statutory bodies.

\section{RESULTS AND DISCUSSION}

194 responses gathered from 291 surveys distributed, which gives a $66.7 \%$ response rate. Responses from federal statutory bodies are 116 (59.8\%), and state statutory bodies are $78(40.2 \%)$. The demographics of the respondents were as in Table 1. 
Table 1. Respondents' Demographic Information

\begin{tabular}{lllll}
\hline $\begin{array}{l}\text { Demographic profiles } \\
\text { Frequency (N=194) }\end{array}$ & Federal & State & $\begin{array}{l}\text { Percent } \\
(\mathbf{\%})\end{array}$ \\
\hline Gender & Male & 58 & 51 & 56.19 \\
& Female & 58 & 27 & 43.81 \\
\hline Age & Less 30 years old & 10 & 4 & 7.22 \\
& 30-40 years old & 42 & 28 & 36.08 \\
& 41-50 years old & 32 & 22 & 27.84 \\
& $51-60$ years old & 29 & 21 & 25.77 \\
& More than 60 years & 3 & 3 & 3.09 \\
\hline Academic & Diploma & 5 & 7 & 6.18 \\
qualification & Bachelor Degree & 55 & 43 & 50.51 \\
& Master Degree & 42 & 22 & 33 \\
& Professional & 9 & 4 & 6.7 \\
\hline Number of years in & Others & 5 & 2 & 3.61 \\
the current position & Less than 5 & 49 & 42 & 46.91 \\
(years) & $11-15$ & 31 & 18 & 25.26 \\
& $16-20$ & 13 & 8 & 10.82 \\
& More than 20 & 6 & 5 & 5.67 \\
\hline Working experience & Less than 5 & 17 & 5 & 11.34 \\
(years) & $5-10$ & 23 & 29 & 26.8 \\
& $11-15$ & 21 & 13 & 17.53 \\
& $16-20$ & 26 & 10 & 18.56 \\
& More than 20 & 19 & 10 & 14.95 \\
\hline
\end{tabular}

The reliability of the items in the questionnaire was excellent (Nunnally, 1978) as the Cronbach's alpha was 0.96 . Therefore, the measurements were valid and reliable.

Table 2. Mean Analysis for Accountability and Accountability's Dimensions

\begin{tabular}{llll}
\hline & & Mean & Std. Dev. \\
\hline Transparency & Federal Statutory Bodies & 5.9978 & .98494 \\
& State Statutory Bodies & 6.0288 & .94918 \\
\hline Stakeholders' & Federal Statutory Bodies & 5.8348 & .92222 \\
Participation & State Statutory Bodies & 5.7094 & .99328 \\
\hline Evaluation & Federal Statutory Bodies & 6.0121 & .98486 \\
& State Statutory Bodies & 6.0154 & 1.09391 \\
\hline Complaint \& & Federal Statutory Bodies & 6.0733 & 1.13301 \\
Response & State Statutory Bodies & 6.2276 & 1.09172 \\
\hline Total & Federal Statutory Bodies & 5.9660 & .90314 \\
Accountability & State Statutory Bodies & 5.9663 & .91864 \\
\hline
\end{tabular}

Table 2 described the score for each accountability elements and the overall accountability outcome score for both federal and state statutory bodies. Based on the table, for federal statutory bodies, complaint and response element was ranked as first, the second was evaluation, followed by transparency and finally, the stakeholders' participation dimension. However, for state statutory bodies, the dimension of complaint and response was first, second was transparency, evaluation as third and finally, the stakeholders' participation. All elements for both statutory bodies showed results of mean above average value. Also, the overall score of accountability for both federal and state statutory bodies was 5.97. This indicated a high level of accountability among statutory bodies in Malaysia.

Both statutory bodies had the highest score and ranked first of complaint and response dimension. The complaint and response in the study indicated that the statutory 
bodies committed confidentiality of complainants, independent investigations, had appeal mechanisms and guaranteed of non-retaliation against complainants. These showed that Malaysian statutory bodies were perfect at handling any internal and external complaints. Many organisations invested in complaint handling as a tool to increase customer commitment, trust and build customer loyalty (Tax, Brown, \& Chandrashekaran, 1998). These should be continuously maintained in statutory bodies' systems as efforts to ensure the satisfaction of stakeholders.

Based on the results of each accountability elements showed that transparency dimension was good and above average for both federal and state statutory bodies and both were highly transparent. However, some studies found that Malaysia had been found to provide minimal information on government's financial activities and this made it hard for citizens to hold government accountable for public money management (Abu Bakar, Saleh, \& Mohamad, 2011). However, if the top management concerned for secrecy on certain matter, stressing for transparency could be seen as a threat (Barrett, 2002b). Hence, government organisations like statutory bodies should take proper and relevant transparent measurements because it could increase reputation to the public (Harrison \& Sayogo, 2014). Transparency would also lead to effective and timely action, thus improving the processes of scrutiny and helped to ensure that public organisations were fully responsible for activities conducted (Barrett, 2002a).

In addition, the evaluation dimension had played an important dimension in accountability. In this study, the evaluation of statutory bodies was evaluating the real performance being against its strategic plan, operations management and internal administration; timely and continuously. Though in federal statutory bodies ranked as second and in state statutory bodies ranked as third, it scored above average. Evaluation could be seen as institutionalised practice, influencing and shaping public perception, and a reflection of values (Carman, 2013). Hence, its empowerment would teach organisations to face challenges related to program planning, implementation, and evaluation (Wandersman, Alia, Cook, Hsu, \& Ramaswamy, 2016). Accountability had evolved for the evaluation of an organisation to be more careful in planning its strategy and programmes (Carman, 2013). Hence, an increase in evaluation obligation would be good for the measurement of effectiveness (Carman, 2009) and quality improvement (Leviton, 2016), which will increase the accountability of the organisation.

Looking at federal and state statutory bodies, both organisations had dimensions of stakeholders' participation in the last place. Therefore, the result should be taken into consideration by both statutory bodies to improve in their engagement with both internal and external stakeholders. Accountability was seen as democratization because it involved planned public network and participation in policy and decision making (Blair, 2000; Lewis, Isbell, \& Koschmann, 2010; Olsen, 2013) and ensured discretion about stakeholders' interests (Brandsma \& Schillemans, 2012). Strong participation would foster fair control of organisation and quality engagement of stakeholders (Lloyd et al., 2008). Allowing stakeholders' participation was an important policy goal for accountability since it could be a useful measure in an attempt to balance the power of regulatory (Hess, 2007).

Further, there were many studies indicate that the developing country's public administration usage of social networks motivates the citizens to take part in public affairs and this increase the effectiveness of public goods services, for example like Thailand (Suebvises, 2018). Hence, current participation would be much easier for statutory bodies since social media, websites and the internet could be used to actively engage with the stakeholders. Almost all statutory bodies had websites to engage with the people. However, the implementation of it and whether was user-friendly, updated and prompted response as expected was still an issue. This was because many statutory bodies did not update the info in their website and social media and the page was dormant. This could 
demotivate the stakeholders and citizen to participate and gave inputs to the statutory bodies for better accountability.

Next, an independent T-test was conducted to compare accountability's mean score between federal and state statutory bodies. The test could be conducted to compare both groups' mean as the response were more than 30; hence, normality would not be an issue. The results were shown in Table 3.

The transparency Sig. value for Levene's test was larger than .05, which was .729., and hence, Equal variances assumed. There was no significant difference in the transparency score between federal $(M=5.9978, S D=.98494)$ and state statutory bodies $(\mathrm{M}=6.0288, \mathrm{SD}=.94918) ; \mathrm{t}(192)=-.218, \mathrm{p}=.828$ (two-tailed).

The stakeholders' participation Sig. value for Levene's test was larger than .05, which was .253and hence, Equal variances assumed. There was no significant difference in the stakeholders' participation score between federal $(\mathrm{M}=5.8348, \mathrm{SD}=.92222)$ and state statutory bodies $(\mathrm{M}=5.7094, \mathrm{SD}=.99328) ; \mathrm{t}(192)=.90, \mathrm{p}=.369$ (two-tailed).

The evaluation Sig. value for Levene's test was larger than .05, which was .939 and hence, Equal variances assumed. There was no significant difference in the evaluation score between federal $(M=6.0121, S D=.98486)$ and state statutory bodies $(M=6.0154$, $\mathrm{SD}=1.09391) ; \mathrm{t}(192)=-.022, \mathrm{p}=.982$ (two-tailed).

The complaint and response Sig. value for Levene's test was larger than .05, which was .465 and hence, Equal variances assumed. There was no significant difference in the complaint and response score between federal $(M=6.0733, S D=1.13301)$ and state statutory bodies $(M=6.2276, S D=1.09172) ; t(192)=-.944, p=.347$ (two-tailed).

The accountability Sig. value for Levene's test was larger than .05, which was .826and hence, Equal variances assumed. There was no significant difference in the accountability score between federal $(M=5.9660, S D=.90314)$ and state statutory bodies $(M=5.9663$, $\mathrm{SD}=.91864) ; \mathrm{t}(192)=-.002, \mathrm{p}=.998$ (two-tailed).

Further, the effect size for independent sample T-test provided the magnitude of differences between the two groups (Pallant, 2016). It could be known by calculating eta squared.

Eta squared $\quad=\mathrm{t}^{2} / \mathrm{t}^{2}+(\mathrm{N} 1+\mathrm{N} 2-2)$ 
Table 3. Independent Samples Test

\begin{tabular}{|c|c|c|c|c|c|c|c|c|c|c|}
\hline & & \multicolumn{2}{|c|}{$\begin{array}{l}\text { Levene's Test for } \\
\text { Equality of } \\
\text { Variances } \\
\end{array}$} & \multicolumn{7}{|c|}{ t-test for Equality of Means } \\
\hline & & \multirow[t]{2}{*}{$\mathrm{F}$} & \multirow[t]{2}{*}{ Sig. } & \multirow[t]{2}{*}{$\mathrm{t}$} & \multirow[t]{2}{*}{ df } & \multirow[t]{2}{*}{$\begin{array}{l}\text { Sig. }(2- \\
\text { tailed) }\end{array}$} & \multirow[t]{2}{*}{$\begin{array}{c}\text { Mean } \\
\text { Difference }\end{array}$} & \multirow[t]{2}{*}{$\begin{array}{l}\text { Std. Error } \\
\text { Difference }\end{array}$} & \multicolumn{2}{|c|}{$\begin{array}{l}95 \% \text { Confidence } \\
\text { Interval of the } \\
\text { Difference }\end{array}$} \\
\hline & & & & & & & & & Lower & Upper \\
\hline \multirow[t]{2}{*}{ Transparency } & $\begin{array}{l}\text { Equal variances } \\
\text { assumed }\end{array}$ & .120 & .729 & -.218 & 192 & .828 & -.03100 & .14215 & -.31137 & .24937 \\
\hline & $\begin{array}{l}\text { Equal variances } \\
\text { not assumed }\end{array}$ & & & -.220 & 169.405 & .826 & -.03100 & .14112 & -.30957 & .24757 \\
\hline \multirow[t]{2}{*}{$\begin{array}{l}\text { Stakeholders' } \\
\text { Participation }\end{array}$} & $\begin{array}{l}\text { Equal variances } \\
\text { assumed }\end{array}$ & 1.315 & .253 & .900 & 192 & .369 & .12537 & .13930 & -.14940 & .40013 \\
\hline & $\begin{array}{l}\text { Equal variances } \\
\text { not assumed }\end{array}$ & & & .887 & 156.850 & .376 & .12537 & .14135 & -.15383 & .40457 \\
\hline \multirow[t]{2}{*}{ Evaluation } & $\begin{array}{l}\text { Equal variances } \\
\text { assumed }\end{array}$ & .006 & .939 & -.022 & 192 & .982 & -.00332 & .15082 & -.30079 & .29416 \\
\hline & $\begin{array}{l}\text { Equal variances } \\
\text { not assumed }\end{array}$ & & & -.022 & 153.314 & .983 & -.00332 & .15396 & -.30747 & .30084 \\
\hline \multirow[t]{2}{*}{$\begin{array}{l}\text { Complaint \& } \\
\text { Response }\end{array}$} & $\begin{array}{l}\text { Equal variances } \\
\text { assumed }\end{array}$ & .535 & .465 & -.944 & 192 & .347 & -.15429 & .16351 & -.47679 & .16821 \\
\hline & $\begin{array}{l}\text { Equal variances } \\
\text { not assumed }\end{array}$ & & & -.951 & 169.420 & .343 & -.15429 & .16232 & -.47471 & .16614 \\
\hline \multirow[t]{2}{*}{ Accountability } & $\begin{array}{l}\text { Equal variances } \\
\text { assumed }\end{array}$ & .049 & .826 & -.002 & 192 & .998 & -.00029 & .13316 & -.26294 & .26235 \\
\hline & $\begin{array}{l}\text { Equal variances } \\
\text { not assumed }\end{array}$ & & & -.002 & 163.399 & .998 & -.00029 & .13361 & -.26411 & .26353 \\
\hline
\end{tabular}

Eta squared calculated for transparency was .0002, stakeholders' participation was .0042 , the evaluation was .000 and complaint, and the response was .0046 . Hence, there was no significant difference between federal and state statutory bodies in their dimensions of accountability since their eta squared were very small.

Eta squared for accountability $\quad=-.002^{2} /-.002^{2}+(116+78-2)$

$$
=.000
$$

Hence, as proposed by Cohen (1988) as stated in Pallant (2016) that the magnitude of differences in the means of accountability (Mean Difference $=-.00029,95 \%$. Confidence Interval $=-.26294$ to .26235 ) was very small (eta squared $=.000$ ).

Many studies separated federal and stated statutory bodies and did a study only focusing on one type of organisation due to their differences in term of legislation, systems, roles, and coverage of responsibilities and accountability. Hence, future studies regarding statutory bodies could be combined since it had been proven that there was no significant difference between them based on their accountability or performances. Issues and problems faced by them also being highlighted by the Auditor General report annually. There was no information stated that one was better than the other. Combination of both would not affect the study. However, a certain measure could be taken in a bigger framework in studies of both federal and state statutory bodies.

The changes in public sector administration had revised the government's role with current emerging trends of globalisation and information age. These had increased complexity and hybrid organisational forms, as well as new accountability challenges (Christensen \& Laegreid, 2007). It also transformed the way the government did business and rising expectations of the public (Barrett, 2002a). Thus, the government needs to have powerful mechanisms that hold public organisations to be responsible for their actions (Ackerman, 2004). Stakeholders nowadays demand assurance and results that could satisfy them (Barrett, 2002a). Statutory bodies, as part of a government mechanism, 
should also practice good governance in their business dealing and managing public resources in delivering services. As accountability involves the engagement of stakeholders, more exceptional judgement and protocols integration could be built (Lerner \& Tetlock, 1999) for better improvement of the organisation.

\section{CONCLUSION}

Though the overall accountability score was above average, lots of improvements on the low ranked elements like participation and maintenance of high scored elements need to be done by statutory bodies. The result of the study would help policymakers to take proactive steps to improve accountability in the statutory bodies to serve people excellently and competently.

Future research of statutory bodies could embark in combining both federal and state statutory bodies as they did not have much and significant differences, especially in general organisations issues and problems like governance and accountability. However, in a bigger research framework, their types of organisations could be the controlling variable for more accurate and reliable research results.

There are some limitations to this study. First, the result of the study could not be used to generalise to the whole Malaysia public sector organisations. A future study could be conducted to cover other types of organisations in the public sector. Further independent T-test could also be conducted to measure whether they had differences for further generalisation and improvements in the research conducted.

\section{ACKNOWLEDGEMENTS}

The authors would like to thank the Accounting Research Institute of University Teknologi MARA for the support given to make this research a success. Thank you to all participating respondents that had served their time and commitment for this research.

\section{REFERENCES}

Abu Bakar, N. B., Saleh, Z., \& Mohamad, M. H. S. (2011). Enhancing Malaysian Public Sector Transparency and Accountability: Lessons and Issues. European Journal of Economics, Finance and Administrative Sciences, 31, 133-145.

Ackerman, J., (2004). Co-governance for Accountability: Beyond "Exit" and "Voice." World Development, 32(3), 447-463.

Ammeter, A. P., Douglas, C., Ferris, G. R., \& Goka, H. (2004). A Social Relationship Conceptualization of Trust and Accountability in Organizations. Human Resource Management Review, 14, 47-65.

Barrett, P. (2002a). Achieving Better Practice Corporate Governance in the Public Sector.

Barrett, P. (2002b). Expectation, and Perception, of Better Practice Corporate Governance in the Public Sector from an Audit Perspective.

Behn, R. D., (2001). Rethinking Democratic Accountability. Brookings Institution Pres.

Blair, H., (2000). Participation and Accountability At the Periphery: Democratic Local Governance in Six Countries. World Development, 28(1), 21-39.

Bovens, M., (2007). Analysing and Assessing Accountability : A Conceptual Framework. European Law Journal, 13(4), 447-468.

Bovens, M., (2010). Two Concepts of Accountability: Accountability as a Virtue and as a Mechanism. West European Politics, 33(5), 946-967.

Bovens, M., Goodin, R., \& Schillemans, T. (2014). The Oxford Handbook of Public Accountability. United Kingdom: Oxford University Press.

Brandsma, G. J., \& Schillemans, T. (2012). The Accountability Cube: Measuring Accountability. Journal of Public Administration Research and Theory, 1-24. 
Carman, J. G., (2009). Nonprofits, Funders, and Evaluation. Accountability in Action? The American Review of Public Administration, 39(4), 374-390.

Carman, J. G., (2013). Evaluation in an Era of Accountability: Unexpected Opportunities - A Reply to Jill Chouinard. American Journal of Evaluation, 34(2), 261-265.

Christensen, T., \& Laegreid, P., (2007). The Whole-of-Government Approach to Public Sector Reform. Public Administration Review, 1059-1066.

Denhardt, R. B., (2008). Theories of Public Organizations (Fifth). Thomson Wadsworth.

Dubnick, M. J., \& Frederickson, H. G. (2011). Public Accountability: Performance Measurement, the Extended State and the Search for Trust.

Ebrahim, A., (2005). Accountability Myopia: Losing Sight of Organizational Learning. Nonprofit and Voluntary Sector Quarterly (Vol. 34).

Engelen, A., Gupta, V., Strenger, L., \& Brettel, M. (2015). Entrepreneurial Orientation, Firm Performance, and the Moderating Role of Transformational Leadership Behaviors. Journal of Management, 41(4), 1069-1097.

Hanretty, C., \& Koop, C., (2014). Independence, Accountability, and the Quality of Regulatory Decision-Making.

Hanretty, C., Larouche, P., \& Reindl, A. (2012). Independence, Accountability and Perceived Quality of Regulators. Brussels.

Harrison, T. M., \& Sayogo, D. S. (2014). Transparency, Participation, and Accountability Practices in Open Government: A Comparative Study. Government Information Quarterly, 31, 513-525.

Hess, D., (2007). Social Reporting and New Governance Regulation: the Prospects of Achieving Corporate Accountability Through Transparency. Business Ethics Quarterly, 17(3), 453-476.

Hyndman, N., \& Liguori, M., (2016). Public Sector Reforms: Changing Contours on an NPM Landscape. Financial Accountability \& Management, 32(1), 5-32.

Kloot, L., (1999). Performance Measurement and Accountability in Victorian Local Government. International Journal of Public Sector Management, 12(7), 565-583.

Kolk, A., (2008). Sustainability, Accountability and Corporate Governance: Exploring Multinationals' Reporting Practices. Business Strategy and the Environment, 1-19.

Lerner, J. S., \& Tetlock, P. E. (1999). Accounting for the Effects of Accountability. Psychological Bulletin, 125(2), 255-275.

Leviton, L. C., (2016). Codifying Practice Into Theory: Commentary on Wandersman et al. American Journal of Evaluation, 1-6.

Lewis, L., Isbell, M. G., \& Koschmann, M. (2010). Collaborative Tensions: Practitioners' Experiences of Interorganizational Relationships. Communication Monographs, 77(4), 460479.

Lindkvist, L., \& Llewellyn, S., (2003). Accountability, Responsibility and Organization. Scandinavian Journal of Management, 19, 251-273.

Lloyd, R., Oatham, J., \& Hammer, M. (2007). 2007 Global Accountability Report. One World Trust.

Lloyd, R., Warren, S., \& Hammer, M. (2008). 2008 Global Accountability Report. One World Trust.

Mabillard, V., \& Zumofen, R. (2016). The Complex Relationship Between Transparency and Accountability: A Synthesis and Contribution to Existing Frameworks. Public Policy and Administration, 1-20.

Mohanty, R. P. (1993). The importance of accountability in managing productivity. Work Study, 42(5), 13-14.

National Audit Department of Malaysia. (2015a). Auditor General's Report; Synopsis on the Audit of Activities of the Federal Statutory Bodies, Management of Subsidiary Companies and Certification of Financial Statement, Series 2.

National Audit Department of Malaysia. (2015b). Auditor General's Report; Synopsis on the Audit of Activities of the Federal Statutory Bodies and the Management of Subsidiary Companies and Financial Management, Series 1.

National Audit Department Malaysia. (2016a). Auditor General's Report 2016. Activities Management/Department/Agencies' Financial and Companies' Management of Kedah Government. Series 1. National Audit Department Malaysia.

National Audit Department Malaysia. (2016b). Auditor General's Report 2016. Activities Management/Department/Agencies' Financial and Companies' Management of Kelantan Government. Series 1. National Audit Department Malaysia. 
National Audit Department Malaysia. (2016c). Auditor General's Report 2016. Activities Management/Department/Agencies' Financial and Companies' Management of Malacca Government. Series 1. National Audit Department Malaysia.

National Audit Department Malaysia. (2016d). Auditor General's Report 2016. Activities Management/Department/Agencies' Financial and Companies' Management of Pahang Government. Series 1. National Audit Department Malaysia.

National Audit Department Malaysia. (2016e). Auditor General's Report 2016. Activities Management/Department/Agencies' Financial and Companies' Management of Perlis Government. Series 1. National Audit Department Malaysia.

National Audit Department Malaysia. (2016f). Auditor General's Report 2016. Activities Management/Department/Agencies' Financial and Companies' Management of Terengganu Government. Series 1. National Audit Department Malaysia.

National Audit Department Malaysia. (2016g). Auditor General's Report 2016 on Financial Statement Federal Government and Financial Management of Ministries/Departments/Federal Statutory Bodies.

Nunnally, J. C., (1978). Psychometrics Theory (2nd ed.). New York: McGraw-Hill.

OECD. (2013). Accountability and Democratic Governance: Orientations and Principles for Development.

Olsen, J. P., (2013). The Institutional Basis of Democratic Accountability. West European Politics, 36(3), 447-473.

Osborne, S. P., (2006). The New Public Governance? Public Management Review, 8(3), 377-387.

Osborne, S. P., (2010). The New Public Governance?: Emerging Perspectives on the Theory and Practice of Public Governance. (S. P. Osborne, Ed.) Routledge (First edit).

Osborne, S. P., Radnor, Z., \& Nasi, G. (2012). A New Theory for Public Service Management? Toward a (Public) Service-Dominant Approach. American Review of Public Administration, 43(2), 135-158.

Pallant, J., (2016). SPSS Survival Manual (6th ed.). London: McGraw Hill Education.

Pollitt, C., (2003). The Essential Public Manager. Philadelphia: Open University Press.

Reichersdorfer, J., Christensen, T., \& Vrangbaek, K. (2013). Accountability of Immigration Administration: Comparing Crises in Norway, Denmark and Germany. International Review of Administrative Sciences, 79(2), 271-291.

Romzek, B. S., (2000). Dynamics of Public Sector Accountability in an Era of Reform. International Review of Administrative Sciences, 66(100), 21-44.

Romzek, B. S., \& Dubnick, M. J. (1987). Accountability in the Public Sector: Lessons from the Challenger Tragedy. Public Administration Review, 47(3), 227-238.

Seidman, H., (1954). The Government Corporation: Organization and Controls. Public Administration Review1, 14(3), 183-192.

Shariman, J., Nawawi, A., \& Salin, A. S. A. P. (2018). Issues and Concerns on Statutory Bodies and Federal Government - Evidence from Malaysian Auditor General's Report. International Journal of Public Sector Performance Management, 4(2).

Siddiquee, N. A. (2005). Public Accountability in Malaysia: Challenges and Critical Concerns. International Journal of Public Administration, 28(1), 107-129.

Simonson, I., \& Staw, B. M. (1992). Deescalation strategies: A comparison of techniques for reducing commitment to losing courses of action. Journal of Applied Psychology, 77(4), 419426.

Suebvises, P., (2018). Social Capital, Citizen Participation in Public Administration, and Public Sector Performance in Thailand. World Development, 109, 236-248.

Tax, S. S., Brown, S. W., \& Chandrashekaran, M. (1998). Customer Evaluations of Service Complaint Experiences: Implications for Relationship Marketing. The Journal of Marketing, 62(April), 60-76.

Thynne, I. (2006). Statutory Bodies: How Distinctive and in What Ways? Public Organization Review, 6, 171-184.

Wandersman, A., Alia, K., Cook, B. S., Hsu, L. L., \& Ramaswamy, R. (2016). Evidence-Based Interventions Are Necessary but Not Sufficient for Achieving Outcomes in Each Setting in a Complex World: Empowerment Evaluation, Getting To Outcomes and Demonstrating Accountability. American Journal of Evaluation, 1-18. 